\title{
Crop Geometry and Fertility Levels Effect on Growth and Productivity of Clusterbean [Cyamopsis tetragonoloba (L.) Taub]
}

\author{
Neha Singh Kirar*, G. S. Rawat, Sarika Mahor, Kavita Bhadu, \\ Roop Singh Dangi and Sudharshan Chicham
}

\author{
Department of Agronomy, RVSKVV, College of Agriculture, Gwalior (M.P.), India
}

*Corresponding author

\begin{tabular}{l} 
K e y w o r d s \\
$\begin{array}{l}\text { Clusterbean, Crop } \\
\text { geometry, Fertility } \\
\text { levels, Productivity }\end{array}$ \\
Article Info \\
$\begin{array}{l}\text { Accepted: } \\
\text { 05 February } 2020 \\
\text { Available Online: } \\
\text { 10 March } 2020\end{array}$ \\
\hline
\end{tabular}

Keywords

Clusterbean, Crop geometry, Fertility evels, Productivity

Article Info

Accepted:

February 2020

Available Onlin

\author{
A B S T R A C T
}

A field experiment was conducted during Kharif season of 2016 at College of Agriculture, Gwalior with a view to assess the effect of crop geometry and fertility levels on growth and productivity of Clusterbean. Experiment was laid out as randomized block design(RBD) replicated thrice with 10 treatments. The study revealed that among different crop geometry treatments, reducing $25 \%$ plant population (by increased plant intra-row spacing) gave significantly higher values of all growth attributes viz., plant height and number of branches/plant; yield attributes viz., number of pods/plant, number of seeds/pod and seed index and yield viz.; seed and stover (kg/ha) over normal plant population $45 \mathrm{~cm} \times 10 \mathrm{~cm}$ and increasing $25 \%$ plant population, respectively. Similarly, among different fertility levels, application of $\mathrm{Zn}$ and B as a basal dose @ $5 \mathrm{~kg} \mathrm{Zn} / \mathrm{ha}$ and @ $1 \mathrm{~kg}$ $\mathrm{B} /$ ha produced higher values of all growth attributes and yield attributes over rest of the treatments.

\section{Introduction}

Clusterbean [Cyamopsis tetragonoloba (L.) Taub] is an annual legume crop mostly grown under resource constrained conditions in arid and semi-arid regions (Kumar, 2005). Cluster bean is a deep rooted plant of Leguminosae (Fabaceae) family known for drought and high temperature tolerance (Kumar and Rodge, 2012). It is used as vegetable, forage, green manure and also for the water soluble gum. It is a rich source of protein, fats, carotenes, Phosphorus, Calcium and mineral salt needed in the foods for human beings, feeds and fodder for animals. It contains $42 \%$ crude protein as well as 29 to 31.4 per cent gum (Kumar and Rodge, 2012). India is one of the main producers of clusterbean accounting $82 \%$ of the total production of the world, and the same is grown in the northwestern states of India, namely Rajasthan, Gujarat, Haryana, Punjab and some parts of 
Uttar Pradesh and Madhya Pradesh. In India clusterbean is being grown in the area of 4.25 million hectares with a production of 2.42 million tonnes of clusterbean seed with an average productivity of $567 \mathrm{~kg} / \mathrm{ha}$. In M.P., Clusterbean is cultivated as pure crop in 75280 ha (Anonymous, 2015).

The yield of clusterbean can be increased through improved agronomic manipulations such as proper crop geometry and judious use of fertilizer. The optimum planting geometry ensures the plant to grow in their both aerial and underground parts through efficient utilization of solar radiation and nutrients (Miah et al., 1990). Closer planting geometry hampers intercultural operations, more competition arises among the plant for nutrient, air and light as a result plant become weaker and thinner and consequently, yield is reduced. So it is most important to determine optimum crop geometry for maximizing the yield of clusterbean.

Clusterbean responds well to phosphorus (P) rather than nitrogen( $\mathrm{N})$. Since, $\mathrm{N}$ fixing legumes usually require more phosphorus than nitrogen because phosphorus plays a very vital role in the nodule development and their activity (Serraj et al., 2004). In recent years, the continuous application of only nitrogen and phosphorus led to the deficiency of micronutrients in arid soil. Deficiency of Zinc $(\mathrm{Zn})$ in soil causes deficiency in crops and altogether this has become a problem all over the world with acute zinc deficiency ranges in arid and semi-arid regions of the world (Rashid and Ryan, 2004). Deficiency of micro nutrients has more detrimental effects on metabolic pathways, enzyme activities, performance of crops and uptake of micronutrients. Zinc application significantly increased the nitrogen activity, carbohydrate and protein content in clusterbean (Nandwal et al., 1990). Poor management of fertilizer is the main culprit of low productivity.
Therefore, to achieve optimum crop productivity, it is crucial to have better management of nutrients through judicious application. Considering the facts and views highlighted above, the present study was planned to study the effect of crop geometry and fertility levels on growth and yield of Kharif Clusterbean.

\section{Materials and Methods}

The field experiment was conducted during Kharif 2016 at the College of Agriculture, Gwalior (M.P.). Gwalior is located at $26^{0} 13^{\text {, }}$ North latitude and $78^{0} 14^{\prime}$ 'East longitude and 208 meteres above mean sea level. It lies in the North tract of Madhya Pradesh, enjoying subtropical climate, with extreme hot about $48^{\circ} \mathrm{C}$ in summer and minimum temperature $4.0^{\circ} \mathrm{C}$ in the winter season. The annual rainfall ranges between 750 to $800 \mathrm{~mm}$, most of which received from end of June to end of September, with few showers in winter months. The soil of the experimental field was sandy clay loam. Soil of the experimental field was rich in potash content $(240.50$ $\mathrm{kg} / \mathrm{ha}$ ), but low in organic carbon $(0.40 \%)$, available nitrogen $(210.50 \mathrm{~kg} / \mathrm{ha})$ and medium in available phosphorus contents $(14.50$ $\mathrm{kg} / \mathrm{ha})$. It is slightly alkaline in reaction $(\mathrm{pH}$ 8.0) and had moderate cation exchange capacity. The experiment was conducted in RBD with three replications. The experiment consist of 10 treatments viz., Normal plant population $45 \mathrm{~cm} \times 10 \mathrm{~cm}$ (as per state recommended row and plant spacing),25\% Reduction in Plant population (by increased plant intra-row spacing), $25 \%$ increase in plant population (by reduced plant intra-row spacing), Foliar spray of urea @ 1\% at vegetative stage along with PP chemicals, Seed treatment with Rhizobium + PSB, Foliar spray of micronutrients @ $1 \%$ (Zinc and Boron) at vegetative stage, Foliar spray of water soluble fertilizer 19:19:19 @ 1\% at vegetative stage, Application of FYM @ 2.5 
t/ha, Crop residue retention @ 3 t/ha, Application of $\mathrm{Zn}$ and Boron as a basal dose @ 5kg Zn/ha and @ 1kg B/ha.. Clusterbean variety 'HG- 563' was sown on $21^{\text {st }}$ July 2016 at a row spacing of $45 \times 10 \mathrm{~cm}$ using seed rate of $20 \mathrm{~kg} / \mathrm{ha}$ and fertilized with $20: 40: 20$ NPK $\mathrm{kg} / \mathrm{ha}$. All the growth and yield attributes were recorded using standard procedure. The crop growth rate(CGR), relative growth rate(RGR) and absolute growth rate(AGR) was calculated using the standard procedure and formula.

\section{Crop Growth Rate (g/m²/day)}

Crop growth rate (CGR) is the rate of dry matter production per unit ground area per unit time. CGR was calculated by adopting the formula as suggested by Watson (1952) and expressed as $\mathrm{g} / \mathrm{m}^{2} /$ day.

$\operatorname{CGR}\left(\mathrm{g} / \mathrm{m}^{2} /\right.$ day $)=$

$\frac{\mathrm{W}_{2}-\mathrm{W}_{1}}{\mathrm{t}_{2}-\mathrm{t}_{1}} \times \frac{1}{\mathrm{~A}}$

Where,

$\mathrm{W}_{1}=$ Dry weight of the plant $(\mathrm{g})$ at time $\mathrm{t}_{1}$

$\mathrm{W}_{2}=$ Dry weight of the plant $(\mathrm{g})$ at time $\mathrm{t}_{2}$

$\mathrm{t}_{2}-\mathrm{t}_{1}=$ Time interval in days

$\mathrm{A}=$ Unit land area occupied by the plant $\left(1 \mathrm{~m}^{2}\right)$

\section{Relative Growth Rate (g/g/day)}

It is the rate of increase in the dry weight per unit dry weight already present and is expressed as g/g/day (Blackman, 1919).

Relative growth rate at various stages was calculated as follows:-

Relative Growth Rate $($ RGR) $=$

$$
\frac{\left(\log _{\mathrm{e}} \mathrm{W}_{2}-\log _{\mathrm{e}} \mathrm{W}_{1}\right)}{\left(\mathrm{t}_{2}-\mathrm{t}_{1}\right)}
$$

Where,

$\mathrm{W}_{1}=$ Dry weight of plant $(\mathrm{g})$ at time $\mathrm{t}_{1}$

$\mathrm{W}_{2}=$ Dry weight of plant $(\mathrm{g})$ at time $\mathrm{t}_{2}$ $\mathrm{t}_{2}-\mathrm{t}_{1}=$ Time interval in days

\section{Absolute Growth Rate (g/day)}

Absolute growth rate (AGR) is the dry matter production per unit time ( $\mathrm{g} /$ day), which was calculated by using the formula as given by Radford (1967).

Absolute Growth Rate (g/day) $=\frac{\mathrm{W}_{2}-\mathrm{W}_{1}}{\mathrm{t}_{2}-\mathrm{t}_{1}}$

Where,

$\mathrm{W}_{1}=$ Dry weight of the plant $(\mathrm{g})$ at time $\mathrm{t}_{1}$

$\mathrm{W}_{2}=$ Dry weight of the plant $(\mathrm{g})$ at time $\mathrm{t}_{2}$

The plant sample were collected at 30,60,90 and at harvest days after sowing. The samples were dried in the oven at $650 \mathrm{C}$ for 3 days or until the dry weight was stabilized. The samples were weighed using an electronic balance.

\section{Results and Discussion}

\section{Growth parameters}

The effect of crop Geometry treatments on various growth indices is shown in Table 1. The result revealed that treatment of reducing $25 \%$ plant population produced significantly higher values of all growth attributes viz., the plant height $(104.81 \mathrm{~cm})$, number of branches per plant(8.54), Dry weight per plant(49.61), crop growth rate $(10.60 \mathrm{~g})$, relative growth rate(10.72) and absolute growth rate(0.0471)over treatment of Increasing 25\% plant population and Normal plant population $45 \mathrm{~cm} \times 10 \mathrm{~cm}$, respectively. It may be due to wider row to row spacing allows the plant to attain their normal growth to express their full potential. 
Table.1 Effect of crop geometry and fertility levels on growth of Clusterbean

\begin{tabular}{|c|c|c|c|c|c|c|c|c|c|c|c|c|c|c|c|c|c|c|}
\hline \multirow[t]{2}{*}{ Treatment } & \multirow{2}{*}{$\begin{array}{l}\text { Plant } \\
\text { height } \\
\text { at } \\
\text { harvest } \\
\text { (cm) }\end{array}$} & \multirow{2}{*}{$\begin{array}{c}\text { No. of } \\
\text { branches } \\
\text { per plant } \\
\text { at } \\
\text { harvest }\end{array}$} & \multicolumn{4}{|c|}{$\begin{array}{c}\text { Dry Weight(g/plant) } \\
\text { at }\end{array}$} & \multicolumn{4}{|c|}{ CGR(g/m2/day) at } & \multicolumn{4}{|c|}{ RGR(g/g/day) at } & \multicolumn{4}{|c|}{$\operatorname{AGR}(g / d a y)$ at } \\
\hline & & & $\begin{array}{l}\text { 30 } \\
\text { DAS }\end{array}$ & $\begin{array}{l}60 \\
\text { DAS }\end{array}$ & $\begin{array}{l}90 \\
\text { DAS }\end{array}$ & Maturity & $\begin{array}{l}\text { 30 } \\
\text { DAS }\end{array}$ & $\begin{array}{l}60 \\
\text { DAS }\end{array}$ & $\begin{array}{l}90 \\
\text { DAS }\end{array}$ & Maturity & $\begin{array}{l}\text { 30 } \\
\text { DAS }\end{array}$ & $\begin{array}{l}60 \\
\text { DAS }\end{array}$ & $\begin{array}{l}90 \\
\text { DAS }\end{array}$ & Maturity & $\begin{array}{l}\text { 30 } \\
\text { DAS }\end{array}$ & $\begin{array}{l}\text { 60 } \\
\text { DAS }\end{array}$ & $\begin{array}{l}90 \\
\text { DAS }\end{array}$ & Maturity \\
\hline $\begin{array}{l}\text { Normal plant population } \\
45 \mathrm{~cm} \times 10 \mathrm{~cm} \text { (as per } \\
\text { state recommended row } \\
\text { and plant spacing) }\end{array}$ & 88.75 & 7.01 & 2.01 & 9.57 & 21.15 & 27.28 & 1.49 & 5.61 & 8.58 & 4.54 & 23.53 & 50.04 & 25.38 & 8.14 & 0.067 & 0.252 & 0.386 & 0.204 \\
\hline $\begin{array}{l}25 \% \text { reduction in plant } \\
\text { population }\end{array}$ & 104.81 & 8.54 & 2.52 & 13.62 & 35.49 & 49.61 & 1.88 & 8.78 & 15.97 & 10.60 & 31.18 & 55.46 & 28.88 & 10.72 & 0.085 & 0.396 & 0.706 & 0.471 \\
\hline $\begin{array}{l}25 \% \text { increase in plant } \\
\text { population }\end{array}$ & 84.60 & 6.36 & 1.76 & 7.75 & 16.69 & 21.15 & 1.31 & 4.44 & 6.77 & 3.16 & 19.38 & 47.41 & 24.96 & 7.20 & 0.059 & 0.203 & 0.304 & 0.146 \\
\hline $\begin{array}{l}\text { Foliar spray of urea @ } \\
1 \%+\text { PP chemicals }\end{array}$ & 97.16 & 7.52 & 2.50 & 13.60 & 33.24 & 46.35 & 1.85 & 8.06 & 14.53 & 9.72 & 30.61 & 54.10 & 28.58 & 10.62 & 0.083 & 0.372 & 0.654 & 0.437 \\
\hline $\begin{array}{l}\text { Seed treatment with } \\
\text { Rhizobium + PSB }\end{array}$ & 88.68 & 6.65 & 2.02 & 9.72 & 21.77 & 28.35 & 1.50 & 5.70 & 8.94 & 4.88 & 23.78 & 50.28 & 25.87 & 8.45 & 0.067 & 0.256 & 0.402 & 0.219 \\
\hline $\begin{array}{l}\text { Foliar spray of (Zinc and } \\
\text { Boron) @ } 1 \% \\
\text { vegeatative stage }\end{array}$ & 92.33 & 7.39 & 2.14 & 10.37 & 23.41 & 30.77 & 1.58 & 6.09 & 10.27 & 5.54 & 25.38 & 50.43 & 25.82 & 8.74 & 0.072 & 0.274 & 0.435 & 0.245 \\
\hline $\begin{array}{l}\text { Foliar spray of water } \\
\text { soluble fertilizer 19: } 19 \text { : } \\
19 @ 1 \% \text { at vegetative } \\
\text { stage }\end{array}$ & 90.55 & 7.10 & 2.10 & 10.13 & 22.72 & 29.62 & 1.56 & 5.94 & 9.33 & 5.11 & 25.08 & 50.31 & 25.82 & 8.48 & 0.070 & 0.268 & 0.420 & 0.230 \\
\hline $\begin{array}{l}\text { Application of FYM @ } \\
2.5 \mathrm{t} / \mathrm{ha}\end{array}$ & 97.54 & 8.13 & 2.32 & 12.15 & 29.01 & 38.88 & 1.72 & 7.29 & 12.48 & 7.32 & 28.22 & 53.00 & 27.84 & 9.38 & 0.077 & 0.328 & 0.562 & 0.329 \\
\hline $\begin{array}{l}\text { Crop residue retention @ } \\
3 \text { t/ha }\end{array}$ & 96.52 & 8.06 & 2.29 & 11.99 & 28.33 & 37.61 & 1.70 & 7.18 & 12.11 & 6.88 & 27.92 & 52.88 & 26.88 & 9.07 & 0.077 & 0.323 & 0.545 & 0.214 \\
\hline $\begin{array}{l}\text { Application of } \mathrm{Zn} \text { and B } \\
\text { as a basal dose @ } 5 \mathrm{~kg} \\
\mathrm{Zn} / \mathrm{ha} \text { and @ } 1 \mathrm{~kg} \mathrm{~B} / \mathrm{ha}\end{array}$ & 102.51 & 8.16 & 2.36 & 12.40 & 29.73 & 40.16 & 1.75 & 7.44 & 12.86 & 7.73 & 28.79 & 53.08 & 27.98 & 9.63 & 0.079 & 0.334 & 0.578 & 0.348 \\
\hline S.E.(m) \pm & 4.033 & 0.295 & 0.10 & 0.50 & 0.89 & 1.61 & 0.065 & 0.283 & 0.540 & 0.274 & 1.086 & 2.328 & 1.140 & 0.305 & 0.003 & 0.012 & 0.020 & 0.013 \\
\hline C.D. (at 5\%) & 11.98 & 0.876 & 0.29 & 1.50 & 2.66 & 4.79 & 0.194 & 0.840 & 1.604 & 0.815 & 3.226 & 6.917 & 3.388 & 0.905 & 0.009 & 0.036 & 0.062 & 0.040 \\
\hline
\end{tabular}

DAS= Days after Sowing; $*$ MAT $=$ Maturity. 
Table.2 Effect of crop geometry and fertility levels on yield attributes and yield of Clusterbean

\begin{tabular}{|c|c|c|c|c|c|}
\hline Treatment & No. of pods/plant & $\begin{array}{c}\text { No. of } \\
\text { seeds/pod }\end{array}$ & $\begin{array}{l}\text { Seed index } \\
(\mathrm{g})\end{array}$ & $\begin{array}{l}\text { Seed yield } \\
\text { (kg/ha) }\end{array}$ & $\begin{array}{l}\text { Strover yield } \\
\text { (kg/ha) }\end{array}$ \\
\hline $\begin{array}{l}\text { Normal plant population } 45 \mathrm{~cm} \times \\
10 \mathrm{~cm} \text { (as per state recommended } \\
\text { row and plant spacing) }\end{array}$ & 65.62 & 7.22 & 3.21 & 1453.70 & 2527.78 \\
\hline $25 \%$ reduction in plant population & 72.96 & 7.32 & 3.30 & 1583.33 & 2861.11 \\
\hline $25 \%$ increase in plant population & 61.05 & 6.75 & 3.15 & 1324.07 & 2287.37 \\
\hline $\begin{array}{l}\text { Foliar spray of urea @ } 1 \%+\text { PP } \\
\text { chemicals }\end{array}$ & 71.47 & 7.13 & 3.15 & 1527.78 & 2331.48 \\
\hline $\begin{array}{l}\text { Seed treatment with Rhizobium }+ \\
\text { PSB }\end{array}$ & 67.30 & 6.79 & 3.18 & 1324.07 & 2101.85 \\
\hline $\begin{array}{l}\text { Foliar spray of (Zinc and Boron) @ } \\
1 \% \text { vegeatative stage }\end{array}$ & 71.16 & 7.19 & 3.21 & 1365.74 & 2308.33 \\
\hline $\begin{array}{l}\text { Foliar spray of water soluble } \\
\text { fertilizer 19: 19: } 19 @ 1 \% \text { at } \\
\text { vegetative stage }\end{array}$ & 68.23 & 6.87 & 3.18 & 1365.74 & 2393.52 \\
\hline Application of FYM @ 2.5 t/ha & 78.24 & 7.68 & 3.26 & 1777.78 & 2337.03 \\
\hline Crop residue retention @ 3 t/ha & 74.25 & 7.22 & 3.23 & 1564.81 & 2135.19 \\
\hline $\begin{array}{l}\text { Application of } \mathrm{Zn} \text { and B as a basal } \\
\text { dose @ } 5 \mathrm{~kg} \mathrm{Zn/ha} \mathrm{and} \mathrm{@} 1 \mathrm{~kg} \\
\text { B/ha }\end{array}$ & 80.62 & 7.70 & 3.38 & 1859.26 & 2418.52 \\
\hline S.E. $(\mathbf{m}) \pm$ & 2.40 & 0.30 & 0.13 & 76.34 & 202.19 \\
\hline C.D. (at 5\%) & 7.15 & 0.90 & 0.41 & 228.58 & 605.42 \\
\hline
\end{tabular}


Similarly, all the observed growth parameters were significantly influenced under different fertility treatments. Application of $\mathrm{Zn}$ and B as a basal dose@ $5 \mathrm{~kg} \mathrm{Zn/ha} \mathrm{and} \mathrm{@} 1 \mathrm{~kg} \mathrm{B/ha}$ produced significantly higher growth attributing characters, i.e. plant height (102.51), number of branches/plant (8.16) dry weight per plant (40.16), crop growth rate (7.73), relative growth rate (9.63) and absolute growth rate $(0.348)$ at harvest followed by Application of FYM @ $2.5 \mathrm{t} / \mathrm{ha}$ and crop residue retention@ 3t/ha, respectively. The increase may be expected as zinc plays an important role in the production of indole acetic acid, a growth hormone and tryptophan, a precursor of auxin. Further increase in zinc levels i.e. above $5 \mathrm{~kg} / \mathrm{ha}$ caused deleterious effect. The similar result was also reported by Sharma et al., (2004) in Clusterbean. It is a well-known fact that boron is essential in enhancing carbohydrate metabolism, sugar transport, cell wall structure, protein metabolism, root growth and stimulating other physiological process of plant (Ashour and Reda, 1972). The earlier findings of Rawat et al., (2008 and 2010), Rajput et al., (2015), Reddy et al., (2011) also corroborate the present results.

\section{Yield and Yield attributes}

Among different crop geometry treatments, Reducing of $25 \%$ plant population resulted in significantly highest number of pods per plant(72.96), number of seeds per pod(7.22) and seed index $(3.30 \mathrm{~g})$ over treatment of Increasing 25\% plant population and Normal plant population $45 \mathrm{~cm} \times 10 \mathrm{~cm}$, respectively. It may be due widening of space might have provided more nutrients thus resulted in higher production of pods. The seed and strover yield (1583.33 and $2861.11 \mathrm{~kg} / \mathrm{ha})$ were recorded highest in the treatment of reducing $25 \%$ plant population over the treatment of increasing $25 \%$ plant population and normal plant population $45 \mathrm{~cm} \times 10 \mathrm{~cm}$ which might be due to fact that wider planting geometry provide efficient use of nutrient and available resources with less competition .

Similarly among the different fertility treatments, application of $\mathrm{Zn}$ and B as a basal dose@ 5kg Zn/ha and 1-kg B/ha produced significantly highest number of pods per plant(80.62), number of seeds per pod(7.70) and seed index $(3.38 \mathrm{~g})$ over treatment of application of FYM @ 2.5 t/ha and crop residue retention@3t/ha, respectively. The seed and strover yield (1859.26 and 2418.52 $\mathrm{kg} / \mathrm{ha}$ ) were recorded highest in the Application of $\mathrm{Zn}$ and B as a basal dose@ $5 \mathrm{~kg} \mathrm{Zn} / \mathrm{ha}$ and @ $1 \mathrm{~kg} \mathrm{~B} / \mathrm{ha}$ followed by Application of FYM @ 2.5 t/ha and crop residue retention@3t/ha, respectively. The higher yield with zinc application could be ascribed to accelerated nutrient uptake helped the plant to put optimum growth. As these growth and yield attributes showed significant increase seed yield, evidently resulted in higher yields with zinc fertilization. Strover yield was also found significant resulted due to significant response of plant growth parameters viz., plant height, number of branches per plant (Singh and Tiwari 1992). The present findings are in close agreement with the results obtained by Rajput et al., (2015), Salih (2013), Yadav et al., (1991).

\section{References}

Anonymous (2015). Published in Agricultural Statistics at a Glance, Ministry of Agriculture, GOI (New Delhi)

Ashour, N.I., Reda, F. (1972) Effect of foliar application of some micronutrients on growth and some physiological properties of sugar beet growth in winter season. Curr. Sci., 41(4):146-147

Kumar,D.(2005). Status and direction of arid legumes research in India. Indian J.Agric.Sci. 75:375-391.

Kumar,D., Rodge, A.B.(2012). Status, scope and strategies of arid legumes research 
in India: A Review. J. Food Leg. 25:255272

Miah, M.H.N., Karim MA., Rahman MS and Islam MS. 1990. Performance of Nitrogen nutrients under different row spacing. Bangladesh J.Train.Dev 3(2), 31-34.

Nandwal, A., Dabas Bhati, S., Yadav, B.D. (1990). Zinc effect on nitrogen fixation and Clusterbean yield. Annals of Arid Zone. 29:99-103

Rajput,B.S., Gautam, U.S., Dhakad, R., Chaudhary,A.(2015). Find out the suitable treatment combination of phosphorus FYM and PSB on seed yield and economics of cowpea. Ecology, Environment and Conservation paper 21(223-226)

Rashid A, Ryan J(2004). Micronutrient constraints to crop production in soils with Mediterranean-type characteristics: A review. Journal of plant Nutrition.; 27:959-975

Rawat, G.S. and Rawat, Upama(2008). Performance of early maturing Guar [Cyamopsis tetragonoloba (L.) Taub] variety to bio-fertilizer under different fertility levels in northern M.P. Bharatiya Krishi Anusandhan Patrika 23 (3 \&4): 145-148

Rawat, G.S., Rajput, R.L., Rawat, Upama (2010). Response of varying levels of organic manures and PSB on the productivity of Clusterbean[ Cyamopsis tetragonoloba (L.) Taub] Bharatiya Krishi Anusandhan Patrika 24 (1):71-73

Reddy,A.M., Reddy, B.S. (2011). Effect of planting geometry and fertility level on growth and seed yield of clusterbean [Cyamopsis tetragonoloba (L.) Taub] under scarce rainfall zone of Andhra Pradesh. Legume Research (India) 34(2):143-145

Salih, H.O.(2013). Effect of foliar fertilization of $\mathrm{Fe}, \mathrm{B}$ and $\mathrm{Zn}$ on nutrient concentration and seed protein of Cowpea "Vigna Unguiculata". Jour nal of Agriculture and Veterinary Science 6: 42-46.

Serraj, R.., Gyamfi, A.J., Rupela, O.P., Drevan, J. (2004). Improvement of legumes productivity and rate of symbiotic $\mathrm{N}$ fixation in cropping systems: Overcoming the physiological and agronomic limitations. In: Symbiotic Nitrogen Fixation:Prospects for enhanced application in tropical agriculture. Oxford \& IBH publishing Co Pvt. Ltd. New Delhi. pp 68.

Sharma OP, Singh GD(2004). Effect of Sulphur and growth substances on yield, quality and nutrient uptake of clusterbean (Cyamopsis tetragonoloba L. Taub). Journal of Environment and Ecology. 22(4):746-748

Singh T, Tiwari KN (1992). Effect of zinc application on yield and nutrient as influenced by zinc application in pigeonpea. Indian Agriculturist 32(1): 55-61.

Yadav, B.D., Joon, R.K., Loddhi, G.P., Sheoran, R.S. (1991). Effect OF agromanagement practices on the seed yield of Clusterbean. Guar Research Annals 7: 30-33.

\section{How to cite this article:}

Neha Singh Kirar, G. S. Rawat, Sarika Mahor, Kavita Bhadu, Roop Singh Dangi and Sudharshan Chicham. 2020. Crop Geometry and Fertility Levels Effect on Growth and Productivity of Clusterbean [Cyamopsis tetragonoloba (L.) Taub]. Int.J.Curr.Microbiol.App.Sci. 9(03): 1272-1278. doi: https://doi.org/10.20546/ijcmas.2020.903.147 